\title{
Effect of bran particle size on stool weight
}

\author{
A. J. M. BRODRIBB AND CHRIS GROVES
}

From the Radcliffe Infirmary, Oxford, and the Oxford Polytechnic, Oxford

SUMMARY The increase in stool weight after feeding $20 \mathrm{~g}$ (dry weight) of bran daily was measured when this was of large particle size and after milling to small particle size. Twenty-eight investigations were carried out in 21 normal subjects. With coarse bran, stool weight was significantly greater than with the fine bran (mean $219.4 \mathrm{~g} / \mathrm{d}$ coarse bran, $199.0 \mathrm{~g} / \mathrm{d}$ fine bran: difference $20.4 \mathrm{~g} \mathrm{SE} \pm 6.4$, $\mathbf{P}<0.01)$. The coarse bran also had a greater water-holding capacity $(7.3 \mathrm{~g}$ water $/ \mathrm{g}$ coarse bran, $3.9 \mathrm{~g}$ water $/ \mathrm{g}$ fine bran). Coarse bran was $2 \frac{1}{2}$ times the volume of fine bran for a given weight and more fine bran will, therefore, be taken when bran is prescribed by the spoonful.

Wheat bran is now consumed in large quantities as a concentrated form of dietary fibre supplement. Different varieties are available varying in palatability, fibre content, and particle size (Southgate, $1976 \mathrm{a}, \mathrm{b})$. It has been suggested that particle size is important in determining the therapeutic effectiveness of bran (Kirwan et al., 1974). The finer it is, the less its water-holding capacity (McConnell et al., 1974), and the more susceptible in may be to bacterial digestion within the colon (Nutritional Reviews, 1975). A study was, therefore, carried out to determine whether a change in particle size alone affects the laxative properties of bran.

\section{Method}

Twenty-one volunteers, nine men and 12 women, measured their daily stool weight before, during, and after eating coarse and fine bran. This was carried out a total of 28 times, as several subjects repeated the study. The volunteers, aged 20 to 40 years, were doctors, science lecturers, nurses, paramedical staff, technicians, and medical students.

A large quantity of extremely coarse bran was carefully blended and then half of this was hammermilled very finely with no further extraction. Both varieties were sterilised in dry heat at $160^{\circ} \mathrm{C}$ for one hour and were subsequently sterile on culture. The water content of each bran was determined, and the bran divided into portions equivalent to $20 \mathrm{~g}$ dry weight in self-sealing plastic bags.

A normal diet was eaten for the first week of the study and all stool specimens were weighed using spring balances which had previously been checked as accurate to the nearest gram. One type of bran

Received for publication 14 June 1977 was then eaten for two weeks, $20 \mathrm{~g}$ dry weight daily, and all stool specimens weighed during the second week. The other variety of bran was then eaten for two weeks and stool weight measured for the second week. Finally, no bran was eaten for the sixth and seventh weeks and stool weight was measured for the seventh week. Subjects were randomly allocated to eat coarse or fine bran first and were asked to maintain a similar diet throughout the seven week period, without changes in fibre intake apart from the bran.

Dietary fibre, hemicellulose, cellulose, lignin, crude fibre, and neutral detergent fibre values for each bran were obtained (Southgate, 1976b). Particle size was determined by a standardised sieving test in which bran was passed through a series of screens of different mesh size and the weight retained on each was measured. Water-holding capacity was determined by the method described by McConnell et al. (1974), in which the weight of water held by the bran after centrifugation was measured.

\section{Results}

The fibre content, particle size and water-holding capacity of the two types of bran are shown in Table 1.

It will be noted that, while there are only minimal differences in fibre content, there are considerable differences in particle size and water-holding capacity between the two types of bran.

The basal daily stool weight was calculated as the mean of 14 days (first and seventh weeks). The increase in daily stool weight was calculated as the difference between this and the mean daily stool weight for weeks 3 or 5 . The statistical significance 
Table 1 Properties of coarse and fine bran

\begin{tabular}{|c|c|c|c|}
\hline & & $\begin{array}{l}\text { Coarse } \\
\operatorname{bran}(g)\end{array}$ & $\begin{array}{l}\text { Fine } \\
\operatorname{bran}(\mathrm{g})\end{array}$ \\
\hline $\begin{array}{l}\text { Fibre content per } 100 \mathrm{~g} \text { dry wt. } \\
\text { Crude fibre } \\
\text { Neutral detergent fibre } \\
\text { Total dietary fibre } \\
\text { Non-cellulose polysaccharide } \\
\text { Cellulose (as glucose) } \\
\text { Lignin } \\
\text { Particle size distribution } \\
\text { \% by weight of each fraction } \\
\text { (sieve aperture in microns) }\end{array}$ & $\begin{array}{l}>1500 \\
1500 / 710 \\
710 / 500 \\
500 / 210 \\
<210\end{array}$ & $\begin{array}{r}11.8 \\
47.7 \\
49.3 \\
30.4 \\
13.0 \\
5.9\end{array}$ & $\begin{array}{r}12 \cdot 1 \\
48.8 \\
46 \cdot 7 \\
29.9 \\
11.9 \\
4.9\end{array}$ \\
\hline $\begin{array}{l}\text { Water-holding capacity } \\
\text { Wt. of water held by } 1 \mathrm{~g} \text { bran } \\
\text { (dry weight) }\end{array}$ & & $7 \cdot 3$ & 3.9 \\
\hline
\end{tabular}

Table 2 Laxative effect of coarse and fine bran

\begin{tabular}{|c|c|c|c|}
\hline \multicolumn{3}{|c|}{ Mean daily stool weight $(g)$} & \multirow{2}{*}{$\begin{array}{l}\text { Bran eaten } \\
\text { first }\end{array}$} \\
\hline Basal & $\begin{array}{l}\text { Increase with } \\
\text { coarse bran }\end{array}$ & $\begin{array}{l}\text { Increase with } \\
\text { fine bran }\end{array}$ & \\
\hline $\begin{array}{c}47 \\
68 \\
80 \\
81 \\
88 \\
90 \\
93 \\
102 \\
117 \\
120 \\
120 \\
129 \\
133 \\
140 \\
141 \\
142 \\
146 \\
146 \\
147 \\
155 \\
174 \\
185 \\
187 \\
195 \\
202 \\
204 \\
219 \\
272 \\
\text { Mean } 140 \cdot 1\end{array}$ & $\begin{array}{r}6 \\
98 \\
54 \\
78 \\
68 \\
104 \\
42 \\
82 \\
109 \\
78 \\
44 \\
47 \\
15 \\
85 \\
87 \\
154 \\
87 \\
74 \\
56 \\
68 \\
117 \\
72 \\
125 \\
84 \\
122 \\
63 \\
63 \\
139 \\
79 \cdot 3\end{array}$ & $\begin{array}{c}38 \\
43 \\
34 \\
72 \\
34 \\
63 \\
62 \\
21 \\
162 \\
45 \\
63 \\
44 \\
37 \\
54 \\
56 \\
40 \\
89 \\
25 \\
49 \\
25 \\
68 \\
39 \\
78 \\
73 \\
101 \\
70 \\
51 \\
124 \\
58.9\end{array}$ & $\begin{array}{l}\text { Fine } \\
\text { Coarse } \\
\text { Coarse } \\
\text { Coarse } \\
\text { Coarse } \\
\text { Fine } \\
\text { Fine } \\
\text { Fine } \\
\text { Coarse } \\
\text { Fine } \\
\text { Fine } \\
\text { Fine } \\
\text { Coarse } \\
\text { Coarse } \\
\text { Fine } \\
\text { Fine } \\
\text { Coarse } \\
\text { Coarse } \\
\text { Fine } \\
\text { Fine } \\
\text { Coarse } \\
\text { Coarse } \\
\text { Coarse } \\
\text { Coarse } \\
\text { Coarse } \\
\text { Coarse } \\
\text { Fine } \\
\text { Fine }\end{array}$ \\
\hline
\end{tabular}

of the difference between the mean increase in stool weight on coarse and fine bran was calculated by Student's $t$ test. The results are tabulated in Table 2, with the lowest basal stool weight first and the largest last.

The increase in mean stool weight with coarse bran was $79.3 \mathrm{~g}$ and with fine bran $58.9 \mathrm{~g}$. The mean difference in increase between the two was $20.4 \mathrm{~g}$, $\mathrm{SE} \pm 6.4, \mathrm{P}<0.01(t=3.17)$.
The number of bowel actions per week increased with bran from a mean of $7 \cdot 8$ to $10 \cdot 1$ on coarse bran and 9.7 on fine bran. There was no significant difference in defaecation rate between the two types of bran. Those with smaller basal stool weights had a slightly smaller increase in stool weight after bran, but the difference was much less than that of the basal weights.

There was no statistical difference in response to bran between those who ate the fine and those who ate the coarse bran first.

\section{Discussion}

The two types of bran were taken from the same pooled sample and it was, therefore, not surprising that their fibre content was similar. The small differences were almost certainly attributable to sampling problems. It was more difficult to get good replicates with the coarse bran, possibly because of slight fractionation of the sample. The method for determining water-holding capacity was not entirely satisfactory, as the samples did not form coherent pellets on centrifugation, but agreement between duplicates was good. The higher value for the coarse material is probably partly due to water held between individual fragments as opposed to water held within the structure of the fragment. The finer sample would be expected to drain more thoroughly under the test conditions. The present results are comparable with those of Weinreich (1976).

The water content of the bran was variable, especially after sterilising, and all measurements were, therefore, done on a dry weight basis. The water content of each batch was monitored and the bran kept in water-tight containers until it had been weighed out, as water was readily absorbed from the atmosphere.

Cereal fibre is normally eaten after heat treatment as bread, cake, biscuits, or breakfast cereals, so this was not considered detrimental to the value of the study, although the biological effect of cooking cereal fibre has not been clearly defined.

The subjects were allowed to eat their normal diet throughout the study and carefully avoided changes in fibre intake apart from the additional bran. The considerable difference in basal stool weight may reflect differences in the amount of fibre consumed from one individual to another. Other studies in progress suggest that this can vary from less than $3 \mathrm{~g}$ to more than $\mathbf{4 8} \mathrm{g}$ dietary fibre daily. Diet is often different at the weekend compared with the working week, so stool weights were measured for a complete week to allow for such normal fluctuations. Weighing was not difficult with the use of accurate spring balances and was 
found to be a convenient method that allowed for immediate disposal of the specimen. Nearly all subjects had received a scientific training and were used to making precise measurements and keeping accurate records.

The fine bran was much more palatable than the coarse, and most subjects found the latter a struggle. Both types were consumed with breakfast cereals, fruit, or soups mixed with the normal diet. Both tended to cause sensations of fullness, borborygmi, and wind. The stools became soft, solid, of uniform consistency and colour, were more bulky, and often floated.

Table 2 shows that there was considerable individual variation both in basal stool weights and in the response to the two different types of bran. This is probably due, not only to differences in diet and transit time, but also to variations in bacterial flora and innate differences in colonic function. There was much less variation between studies repeated with the same individual.

Coarse and fine brans have previously been compared by Fantus et al. (1941). They detected no difference in stool weight, but different subjects ate coarse and fine bran, the period of bran eating and stool collection for some was only three days, and the dietary fibre content of each type of bran was not shown to be comparable.

Kirwan et al. (1974) studied the effectiveness of two types of commercially available bran in reducing colonic intraluminal pressure and transit time and found that fine bran was less effective than coarse bran after four weeks' treatment. The water-holding capacity of the coarse bran was $6.15 \mathrm{~g}$ water per $\mathrm{g}$ bran and $2.36 \mathrm{~g}$ water per $\mathrm{g}$ for the fine bran. They concluded that the particle size of bran was important in determining stool bulk and therapeutic efficacy. This conclusion has been criticised because the two groups were not closely matched and the amount of fibre present in each bran was different, patients on coarse bran receiving over $3.0 \mathrm{~g}$ acid detergent fibre daily compared with $1.9 \mathrm{~g}$ on fine bran.

The present study shows that particle size is important in determining the effect of bran in increasing stool weight. It can no longer be assumed that fibre of the same chemical composition has the same biological or therapeutic effect on the colon, even if from the same source and consumed in identical quantities. This might explain some of the inconsistencies between different clinical trials.

There are at least three different ways in which particle size could influence stool weight. The larger particles have a higher water-holding capacity and could, therefore, increase the relative amount of water present in the stool. In fact, bran does not greatly increase the percentage water content of the faeces (Cowgill and Anderson, 1932; Wyman et al., 1976), and in vitro water-holding capacity tests may not be relevant to intracolonic behaviour. Coarse bran particles are probably less readily digested by bacteria and this may result in a higher fibre content of the faeces. Williams and Olmstedt (1936) concluded, however, in their classical study that stool weight was probably greater when more fibre was digested within the colon. Thirdly, the larger particles may trap more finely dispersed gas, produced by the colonic bacteria, increasing stool bulk (Walker, 1947) and thereby increasing transit time, with a consequent increase in stool weight. Several subjects noticed that the coarse bran resulted in stools containing more gas bubbles, which floated. All three mechanisms may contribute to the difference between the coarse and fine bran.

Bran is usually prescribed by volume. One spoonful of fine bran was equivalent in weight to $2 \frac{1}{2}$ spoonfuls of coarse bran. A larger weight of fine bran will, therefore, be consumed when measured volumetrically. Similarly, if bran is given ad libitum more of the fine bran will be eaten, as it is more palatable. There is no evidence of a therapeutic difference between coarse and fine bran, provided that the amount taken results in the same increase in stool weight.

We wish to thank The Energen Foods Company, Ashford, Kent, for the supply of bran; Dr D. A. T. Southgate, Dunn Nutrition Laboratory, Cambridge, for the dietary fibre analysis; Dr D. J. Stevens, Flour Milling and Baking Research Association, Chorley Wood, for crude fibre, neutral detergent fibre, particle size and water-holding capacity measurements; Dr D. Quantrell, Radcliffe Infirmary, for bran water content measurements; and particularly the volunteers for their help.

\section{References}

Cowgill, G. R., and Anderson, W. E. (1932). Laxative effects of wheat bran and 'washed bran' in healthy men. Journal of American Medical Association, 98, 1866-1875.

Fantus, B., Hirschberg, N., and Frankl, W. (1941). The mode of action of bran. II. Influence of size and shape of bran particles and of crude fiber isolated from bran. Review of Gastroenterology, 8, 277-280.

Kirwan, W. O., Smith, A. N., McConnell, A. A., Mitchell, W. D., and Eastwood, M. A. (1974). Action of different bran preparations on colonic function. British Medical Journal, 4, 187-189.

McConnell, A. A., Eastwood, M. A., and Mitchell, W. D. (1974). Physical characteristics of vegetable foodstuffs that could influence bowel function. Journal of the Science of Food and Agriculture, 25. 1457-1464.

Nutrition Reviews (1975). Dietary fiber and colonic functionan effect of particle size? Nutrition Reviews, 33, 70-72.

Southgate, D. A. T. (1976a). Dietary fibre (Letter). British 
Medical Journal, 2, 236.

Southgate, D. A. T. (1976b). Analysis of dietary fibre. In Fiber in Human Nutrition. Edited by G. A. Spiller, and R. J. Amen. Plenum Press: New York.

Walker, A. R. P. (1947). The effect of recent changes of food habits on bowel motility. South African Medical Journal, 21, 590-596.

Weinreich, J. (1976). Bran and the irritable bowel (Letter). Lancet, 1, 810-811.
Williams, R. D., and Olmstedt, W. H. (1936). The effect of cellulose, hemicellulose, and lignin on the weight of the stool: a contribution to the study of laxation in man. Journal of Nutrition, 11, 433-449.

Wyman, J. B., Heaton, K. W., Manning, A. P., and Wicks, A. C. B. (1976). The effect on intestinal transit and the feces of raw and cooked bran in different doses. American Journal of Clinical Nutrition, 29, 1474-1479.

\section{The December 1977 Issue}

\section{THE DECEMBER 1977 ISSUE CONTAINS THE FOLLOWING PAPERS}

IgA and IgG reticulin antibodies in coeliac and non-coeliac patients O. E. EADE, R. S. LLOYD, CELIA LANG, AND R. WRIGHT

Localisation of e-antigen in nuclei of hepatocytes in $\mathrm{HB}_{\mathrm{s}}$ Ag-positive liver diseases W. ARNOLD, J. 0. NIELSEN, F. HARDT, AND K. H. MEYER ZUM BÜSCHENFELDE

Immunofluorescence detection of new antigenantibody system $(\delta /$ anti- $\delta$ ) associated to hepatitis B virus in liver and in serum of $\mathrm{HBsAg}$ carriers M. RIZZETTO, M. G. CANESE, S. ARICò, O. CRIVELII, C. TREPO, F. BONINO, AND G. VERME

T-lymphocyte cytotoxicity to $\mathrm{HBsAg-coated} \mathrm{target}$ cells in hepatitis B virus infection A. ALBERTI, G. REALDI, F. BORTOLOTTI, AND A. M. RIGOLI

K-lymphocytes (killer-cells) in Crohn's disease and acute virus B-hepatitis R. ECKHARDT, P. KLOOS, M. P. DIERICH, AND K. H. MEYER ZUM BÜSCHENFELDE

Reduction in peripheral blood $\mathrm{K}$ cells and activated $\mathrm{T}$ cells in primary biliary cirrhosis G. P. SANDILANDS, R. N. M. MACSWEEN, KATHLEEN G. GRAY, R. J. HOLDEN, P. MILlS, FIONA M. REID, MAIR A. THOMAS, AND G. WATKINSON

Pathophysiology of hypotension in patients with fulminant hepatic failure $P$. N. TREWBY AND ROGER WILLIAMS
Clinical study of liver blood flow in man measured by ${ }^{133}$ Xe clearance after portal vein injection $S$. B. SHERRIFF, R. C. SMART, AND I. TAYLOR

Chronic laxative abuse associated with pancreatic islet cell hyperplasia M. LESNA, A. N. HAMLYN, C. W. VENABLES, AND C. O. RECORD

Qualitative and quantitative evaluation of internal anal sphincter function in the newborn $V$. $E$. BOSTON, S. CYWES, AND M. R. Q. DAVIES

Policy of local excision for early cancer of the colorectum B. C. MORSON, H. J. R. BUSSEY, AND S. SAMOORIAN

Giant sigmoid diverticulum: clinical and radiological features D. R. FOSTER AND B. ROSS

Changes in the plasma clearance and protein binding of carbenoxolone with age, and their possible relationship with adverse drug effects M. J. HAYES, MARGARET SPRACKLING, AND M. J. S. LANGMAN

Short report Failure of glucagon to influence ion transport across human jejunal and ileal mucosa in vitro P. E. T. ISAACS AND L. A. TURNBERG

Progress report Transplanation of insulin-secreting tissues R. C. KARL, D. W. SCHARP, W. F. BALLINGER, AND P. E. LACY

Notes and activities

Books

Index to Volume XVIII

Copies are still available and may be obtained from the PUBLISHING MANAGER, BRITISH MEDICAL ASSOCIATION, TAVISTOCK SQUARE, LONDON WC1H 9JR, price $£ 2 \cdot 75$, including postage 